\title{
PERFORMANCE OF BIO-FLUX OIL AS MODIFIER OF BUTON GRANULAR ASPHALT IN ASPHALT CONCRETE-WEARING COURSE
}

\author{
Ratna YUNIARTI ${ }^{1}$ \\ ${ }^{1}$ Department of Civil Engineering, Faculty of Engineering, Mataram University \\ (Jl. Majapahit 62, Mataram 83125, Lombok, Indonesia) \\ E-mail: ratna_yuniarti@yahoo.com
}

\begin{abstract}
A huge deposit of buton natural asphalt in Buton island of South East Sulawesi, Indonesia, has not been fully utilized for asphalt concrete mixture. This is because the asphalt of buton granular asphalt is trapped in mineral, and currently the modifier to rejuvenate buton granular asphalt has not resulted in road pavement that can bear heavy daily traffic. This study aims to examine the performance of bio-flux oil as modifier of buton granular asphalt to determine its asphalt mixture requirement properties. This bio-flux oil consists of the oil derived from the seeds of the oil nut tree (Calophyllum inophyllum L.), crude pine resin from pine tree (Pinus merkusii), and other ingredients in certain composition.
\end{abstract}

Key Words: Calophyllum inophyllum L., Pinus merkusii, bio-flux oil, buton granular asphalt

\section{INTRODUCTION}

In Indonesia, asphalt cement is usually used as a binder in road construction. It is one of many products derived from a barrel of crude oil at a refinery. The price of asphalt cement follows the shifts in oil prices. As crude oil prices increase, so do prices of asphalt cement. Since crude oil is not a renewable natural resource and its reserve is very limited, it is important to save this source of energy.

One approach to reducing the use of asphalt cement as road material is to use natural asphalt. Huge quantities of natural asphalt, locally known as asbuton, are available in Buton island. Asbuton is classified as rock asphalt and is mainly found in two locations, namely, Kabungka and Lawele. Asbuton is produced in the form of particles and consists of two materials: as asphalt itself and the rest is dominantly mineral aggregate. According to Bina Marga (a directorate of the Public Works Ministry of Indonesia) ${ }^{1)}$, the deposit amount of buton granular asphalt is more than 677 million tons. Unfortunately, the utilization of buton granular asphalt has not been optimized yet. The performance of asphalt mixture using buton granular asphalt is lower than that using conventional asphalt cement. This is because the asphalt of buton granular asphalt is trapped in mineral. Heavy bunker oil or flux oil is added to soften the asphalt ${ }^{2)}$.

Nowadays, modifier to rejuvenate buton granular asphalt is being used in road pavement that can bear daily traffic of up to 4,000 vehicles. Meanwhile, a highway with heavy traffic is expected to carry the burden of 8,000-20,000 vehicles/day ${ }^{3)}$. Thus, it is necessary to produce such modifier as buton granular asphalt rejuvenator to improve the ability of asbuton as a binder between the aggregates and fill the void in the asphalt mixture. According to the Transportation Research Board, materials used to alter properties of asphalt cement have been called softening agents, reclaiming agents, modifiers, recycling agents, fluxing oils, extender oils, and aromatic oils ${ }^{4}$.

Bailey and Phillips stated that vegetable oils are excellent fluxes for all bituminous substances and can be used almost indiscriminately for softening asphaltic materials without adversely affecting their weatherresisting qualities or having a detrimental affect on the resulting mixture ${ }^{5}$. One benefit of using sustainable rejuvenations or binders is that they can help save natural resources. Common alternative binders include fossil fuel, biobinder, soybean oil, palm oil, vegetable oil, engine oil residue, grape residues, swine waste, and pyrolized materials, among others. It has been observed that most, if not all, of these alternative binders contain chemical compositions somewhat similar to those of conventional asphalt binders (hydrocarbons, aromatics, saturates, and asphaltenes, etc. $)^{6}$. Wahyudi and Yuniarti concluded that the use of jatropha curcas oil as rejuvenating agent of old asphalt can restore the properties of asphalt pavement recycling mixture ${ }^{7)}$. In addition, Yuniarti stated that 
the use of oil derived from the oil nut tree (Calophyllum inophyllum L.) as part of bio-flux oil can improve the performance of hot mix asphalt containing buton granular asphalt ${ }^{8}$. In this study, the oil extracted from the seeds of Calophyllum inophyllum L., crude pine resin, and other ingredients in certain amounts is used as modifier of buton granular asphalt. This modifier is then called bio-flux oil.

Pine resin from pine tree (Pinus merkusii) is chosen due to a large quantity of resin produced in Indonesia. In 1991, production in Indonesia came from about 100,000 ha of pine. The actual area of planted pine in Java is about four times this figure and still expanding. The potential for increased resin production is therefore very large ${ }^{9}$. In 2012, Perum Perhutani (Forest State Corporation) produced 101,266 tons of pine resin from 163,150 ha of pine forest ${ }^{10)}$. Referring to previous research that sustainable modifier is suitable for buton granular asphalt, this study aims to determine the performance of bio-flux oil in asphalt concrete-wearing course.

The use of vegetable oils or natural resins as rejuvenators or modifiers of asphalt has been mentioned in a number of publications. Neubert in United States Patent number 5,023,282 stated that the use of vegetable oil on asphalt mixture produces a superior asphalt cement that can give low viscosity during application followed by high viscosity, toughness, and tenacity after curing on the highway. The vegetable oils stated in that claim are corn, cottonseed, linseed, olive, peanut, safflower, sunflower, soybean, tall, or tung oils, or mixtures thereof ${ }^{11)}$.

Ballenger et al. in United States Patent number 5,164,002 invented an improved anti-stripping additive for asphalt/aggregate composition used in constructing and repairing highways, pavements, driveways, and parking lots. Said anti-stripping additive consists essentially of citrus terpene (4-isopropyl 1-methylcyclohexene) d-limonene mixed with vegetable oil such as cottonseed oil, soya oil, rapeseed (canola) oil, peanut oil, corn oil, sunflower oil, palm oil, coconut oil, and palm kernel oil, etc. and a silicone oil dispersant ${ }^{12)}$.

Bailey and Phillips in UK Patent Application GB 2462322 stated that sesame oil, sunflower oil, soybean oil, corn oil, palm oil or peanut oil are suitable for the rejuvenating of asphalt ${ }^{5)}$. According to Freisthler in United States Patent number 7,008,670 B1, the sealant composition in his claim includes soy products and other vegetable products, and in another embodiment, the composition is a mixture of asphalt and soy product ${ }^{13)}$.

Williams et al. conducted a research on the use of bio-oils fractions as an extender in original and polymer-modified asphalt binders. They reported that the bio-oils can considerably increase the perfor- mance grade of polymer-modified asphalt binders by nearly $6^{\circ} \mathrm{C}^{14)}$. Nigen-Chaidron et al. in United States Patent number 7,811,372 B2 disclosed bituminous rejuvenating agent and a process for recycling asphalt using the bituminous rejuvenating agent. Said rejuvenating agent consists of 10-90 weight \% palm oil and $90-10$ weight $\%$ asphalt ${ }^{15)}$. In addition, Laurens et al. in United States Patent No. US 8,076,399 B2 disclosed the binder composition comprises a resin of vegetable origin, an oil of vegetable origin and a polymer, and the polymer comprises functional groups chosen from carboxylic acid anhydride, carboxylic acid and epoxide groups ${ }^{16)}$. Moreover, one of the rejuvenators used by Zaumanis et al. is waste vegetable oil ${ }^{17)}$.

From this description, it can be seen that a large amount of rejuvenating agent and binder is processed from oil that can be consumed as food. Since palm oil, soybean oil, etc. can be classified as edible oil, a lot of problems may arise. Food resources are being converted into binder of pavement. Large-scale production of binder from edible oils may bring global imbalance in the food supply and demand market. Competing for the same oil resources has a negative impact on the environment since the expansion of oil crop plantations for binder of pavement may increase deforestation. To overcome this phenomenon, bioflux oil used as modifier in this study consisted of oil extracted from the seeds of Calophyllum inophyllum $L$., crude pine resin, and other ingredients that do not rival any food material.

\section{MATERIALS AND METHODS}

So far, natural asphalt from Kabungka has been widely used in asphaltic concrete as road material in Indonesia. The properties of buton natural asphalt are shown in Table $\mathbf{1}$ and Table 3, and its requirements are presented in Table 2. In this study, buton granular asphalt T5/20 produced by a company in South East Sulawesi was selected. Coarse aggregate, fine aggregate, and filler were collected from an asphalt mix-

Table 1 Chemical properties of asphalt from buton granular asphalt.

\begin{tabular}{|l|c|c|}
\hline \multirow{2}{*}{ Component } & \multicolumn{2}{c|}{ Source of deposit } \\
\cline { 2 - 3 } & Kabungka & Lawele \\
\hline Nitrogen (N) \% & 29.04 & 30.08 \\
\hline Acidaffins (A1) \% & 9.33 & 6.60 \\
\hline Acidaffins (A2) \% & 12.98 & 8.43 \\
\hline Paraffin (P) \% & 11.23 & 8.86 \\
\hline Maltene & 1.50 & 2.06 \\
\hline Nitrogen / Paraffin (\%) & 2.41 & 3.28 \\
\hline Asphaltene content (\%) & 39.45 & 46.92 \\
\hline \multicolumn{2}{|r}{ Source $:$ Bina } \\
\hline
\end{tabular}

Source : Bina Marga ${ }^{1)}$ 
Table 2 Requirements of buton granular asphalt.

\begin{tabular}{|l|c|c|c|c|c|}
\hline \multicolumn{1}{|c|}{ Properties } & Testing method & Type 5/20 & Type 15/20 & Type 15/25 & Type 20/25 \\
\hline Asphalt content (\%) & SNI 03-3640-1994 & $18-22$ & $18-22$ & $23-27$ & $23-27$ \\
\hline $\begin{array}{l}\text { Passing 2.36 mm sieve size (\%) } \\
\text { Passing 1.18 mm sieve size (\%) }\end{array}$ & SNI 03-1968-1990 & $\begin{array}{c}100 \\
\text { minimum 95 }\end{array}$ & $\begin{array}{c}100 \\
\text { minimum 95 }\end{array}$ & $\begin{array}{c}100 \\
\text { minimum 95 }\end{array}$ & $\begin{array}{c}100 \\
\text { minimum 95 }\end{array}$ \\
\hline Water content (\%) & SNI 06-2490-1991 & maximum 2 & maximum 2 & maximum 2 & maximum 2 \\
\hline Penetration, 25 $5^{\circ}$ C, 5 seconds, 0.1 mm & SNI 06-2456-1991 & $\leq 10$ & $10-18$ & $10-18$ & $19-22$ \\
\hline
\end{tabular}

Source : Bina Marga ${ }^{1)}$

Table 3 Chemical properties of mineral from buton granular asphalt.

\begin{tabular}{|l|c|c|}
\hline \multirow{2}{*}{ Component } & \multicolumn{2}{|c|}{ Source of deposit } \\
\cline { 2 - 3 } & Kabungka & Lawele \\
\hline $\mathrm{CaCO}_{3}$ & 86.66 & 72.90 \\
\hline $\mathrm{MgCO}_{3}$ & 1.43 & 1.28 \\
\hline $\mathrm{CaSO}$ & 1.11 & 1.94 \\
\hline $\mathrm{CaS}$ & 0.36 & 0.52 \\
\hline $\mathrm{H}_{2} \mathrm{O}$ & 0.99 & 2.94 \\
\hline $\mathrm{SiO}_{2}$ & 5.64 & 17.06 \\
\hline $\mathrm{Al}_{2} \mathrm{O}_{3}+\mathrm{Fe}_{2} \mathrm{O}_{3}$ & 1.52 & 2.31 \\
\hline Residue & 0.96 & 1.05 \\
\hline \multicolumn{2}{|c}{ Source : Bina Marga } \\
\end{tabular}

Table 4 Aggregate gradation for asphalt concrete-wearing course.

\begin{tabular}{|c|c|c|}
\hline \multicolumn{2}{|c|}{ Sieve sizes } & \% passing \\
\hline ASTM & $(\mathrm{mm})$ & $\begin{array}{c}\text { Asphalt concrete- } \\
\text { wearing course }\end{array}$ \\
\hline $3 / 4 "$ & 19 & 100 \\
\hline $1 / 2 "$ & 12.5 & $90-100$ \\
\hline $3 / 8 "$ & 9.5 & maximum 90 \\
\hline No. 8 & 2.36 & $28-58$ \\
\hline No. 16 & 1.18 & - \\
\hline No. 30 & 0.600 & - \\
\hline No. 200 & 0.075 & $4-10$ \\
\hline \multicolumn{3}{|c|}{ Restricted zone } \\
\hline No. 4 & 4.75 & - \\
\hline No. 8 & 2.36 & 39.1 \\
\hline No. 16 & 1.18 & $25.6-31.6$ \\
\hline No. 30 & 0.600 & $19.1-23.1$ \\
\hline No. 50 & 0.300 & 15.5 \\
\hline
\end{tabular}

ing plant in Pringgabaya, Lombok, Indonesia. Meanwhile, bio-flux oil consisted of oil extracted from the seeds of Calophyllum inophyllum L., crude pine resin, and other ingredients used in this study, namely, B1, B2, B3, B4, and B5. Bio-flux oil B1 consisted of $10 \%$ pine resin and 35\% seed oil; bio-flux oil B2 consisted of $10 \%$ pine resin and $30 \%$ seed oil; bio-flux oil B3 consisted of 5\% pine resin and 35\% seed oil; bio-flux oil B4 consisted of $10 \%$ pine resin and $25 \%$ seed oil; and bio-flux oil B5 consisted of 5\% pine resin and $30 \%$ seed oil.

Mixture design includes determining the proportion of materials in the mixture to meet the speci-
Table 5 Mixture requirements for asphalt concretewearing course.

\begin{tabular}{|l|c|c|}
\hline \multicolumn{1}{|c|}{ Mixture properties } & Unit & $\begin{array}{c}\text { Asphalt concrete- } \\
\text { wearing course }\end{array}$ \\
\hline Number of blows & - & 75 \\
\hline Voids in mix (VIM) & $\%$ & $3.5-5.5$ \\
\hline $\begin{array}{l}\text { Voids in the mineral } \\
\text { aggregate (VMA) }\end{array}$ & $\%$ & minimum 15 \\
\hline $\begin{array}{l}\text { Voids filled with } \\
\text { asphalt (VFA) }\end{array}$ & $\mathrm{kN}$ & minimum 65 \\
\hline Marshall stability & $\mathrm{mm}$ & minimum 3.81 \\
\hline Flow & $\mathrm{kN} / \mathrm{mm}$ & minimum 2.94 \\
\hline Marshall Quotient & $\%$ & minimum 80 \\
\hline Marshall immersion & passes/mm & minimum 2500 \\
\hline Dynamic stability & \multicolumn{2}{|c|}{ Source $:$ Bina Marga } \\
\hline \multicolumn{2}{|c|}{}
\end{tabular}

fications required as shown in Table 4. The mixture made was asphalt concrete-wearing course, the dense mixture of surface course with $4-6 \mathrm{~cm}$ thickness. Asphalt concrete-wearing course should meet the requirements as shown in Table 5.

The value of asphalt content in the mixture was calculated by the empirical formula ${ }^{18)}$ :

$$
\mathrm{Pb}=0.035(\% \mathrm{CA})+0.045(\% \mathrm{FA})+0.18(\% \mathrm{FF})+k
$$

where,

$\mathrm{Pb}$ : estimated optimum asphalt content

$\mathrm{CA}$ : coarse aggregate, percent of aggregate retained on $2.36 \mathrm{~mm}$ sieve

FA : fine agregate, percent aggregate passing 2.36 $\mathrm{mm}$ sieve and retained on $0.075 \mathrm{~mm}$ sieve

FF : filler, \% of aggregate passing $0.075 \mathrm{~mm}$ sieve

$k:$ constant number; the value of 1.0 was taken for asphalt concrete.

The coarse aggregate, fine aggregate, and filler used in this study were $62 \%, 33 \%$, and $5 \%$ respectively, so that the value of $5.56 \%$ was estimated as the optimum asphalt content. Based on the calculation, five asphalt content were applied for each type of asphalt mixture, namely, $4.5 \%, 5 \%, 5.5 \%, 6 \%$, and $6.5 \%$. The percentage of buton granular asphalt added to the mixture was based on the empirical formula from Bina $\operatorname{Marga}^{19)}$ : 
Table 6 Proportion of the mixture.

\begin{tabular}{|l|c|c|c|c|c|}
\hline \multirow{2}{*}{ Proportion of the mixture } & \multicolumn{4}{|c|}{ Asphalt content } \\
\cline { 2 - 6 } & $4.5 \%$ & $5 \%$ & $5.5 \%$ & $6 \%$ & $6.5 \%$ \\
\hline Buton granular asphalt & $10.35 \%$ & $11.50 \%$ & $12.65 \%$ & $13.80 \%$ & $14.95 \%$ \\
\hline Bio-flux oil & $2.79 \%$ & $3.10 \%$ & $3.41 \%$ & $3.72 \%$ & $4.03 \%$ \\
\hline Aggregate & $86.86 \%$ & $85.40 \%$ & $83.94 \%$ & $82.48 \%$ & $81.02 \%$ \\
\hline Total & $100 \%$ & $100 \%$ & $100 \%$ & $100 \%$ & $100 \%$ \\
\hline
\end{tabular}

Percentage of buton granular asphalt $=$ $46 \times$ asphalt content/asphalt content of buton granular asphalt

Modifier $=0.62 \times$ asphalt content

Aggregate $=100 \%-($ buton granular asphalt

$$
+ \text { modifier) }
$$

Buton granular asphalt used in this study was $\mathrm{T} 5 / 20$ that contained $20 \%$ asphalt. Therefore, the proportion of the mixture containing $4.5 \%$ asphalt can be calculated as follows:

Percentage of buton granular asphalt

$$
=46 \times 4.5 / 20=10.35 \%
$$

Modifier $=0.62 \times 4.5=2.79 \%$

$$
\text { Aggregate }=100-(10.35+2.79)=86.86 \%
$$

Proportions of the next mixtures are presented in Table 6.

Gradation of the mixture used in this study referred to the mixture of asphalt concrete-wearing course as shown in Table 4. As stated above, buton granular asphalt contains mineral aggregate. Therefore, gradation of the mixture must be adjusted by mineral aggregate of buton granular asphalt. Combined aggregate with mineral aggregate of buton granular asphalt can be calculated as follows:

- The amount of mineral aggregate per sieve size $=$ percent of mineral content $\times$ percent of buton granular asphalt in the mixture $\times$ percent of mineral passing in each sieve.

- The needed aggregate $=$ gradation of the mixture - mineral of buton granular asphalt in compliance with each sieve size.

Example:

As shown in Table 6, $10.35 \%$ of buton granular asphalt was needed for the mixture containing $4.5 \%$ asphalt. Since buton granular asphalt used in this study was T5/20, which contains $80 \%$ of mineral aggregate, the amount of mineral at $1.18 \mathrm{~mm}$ sieve size $=80 \% \mathrm{x}$ $10.35 \% \times 96.55 \%=7.99 \%$. The needed aggregate $=$ $23 \%-7.99 \%=15.01 \%$.

The combined aggregate gradation with mineral aggregate of buton granular asphalt (BGA) for each asphalt content are presented in Table 7 to Table 11.

Aggregate, buton granular asphalt, and bio-flux oil were mixed at the temperature of $155^{\circ} \mathrm{C}$ and com-
Table 7 Aggregate gradation for $4.5 \%$ asphalt content.

\begin{tabular}{|c|c|c|c|c|}
\hline $\begin{array}{c}\text { Sieve } \\
\text { sizes } \\
(\mathrm{mm})\end{array}$ & $\begin{array}{c}\text { Gradation } \\
\text { of the } \\
\text { mixture } \\
(\% \\
\text { passing })\end{array}$ & $\begin{array}{c}\text { Mineral } \\
\text { of BGA } \\
(\% \\
\text { passing })\end{array}$ & $\begin{array}{c}\text { Mineral } \\
\text { of } \\
10.35 \% \\
\text { BGA }(\% \\
\text { passing })\end{array}$ & $\begin{array}{c}\text { Aggregate } \\
\text { gradation } \\
\text { needed } \\
(\% \\
\text { passing })\end{array}$ \\
\hline 19.00 & 100.00 & & & 100.00 \\
\hline 12.50 & 92.00 & & & 92.00 \\
\hline 9.50 & 76.00 & & & 76.00 \\
\hline 4.75 & 54.00 & & & 54.00 \\
\hline 2.36 & 38.00 & & & 38.00 \\
\hline 1.18 & 23.00 & 96.55 & 7.99 & 15.01 \\
\hline 0.60 & 18.00 & 85.07 & 7.04 & 10.96 \\
\hline 0.30 & 12.50 & 50.16 & 4.15 & 8.35 \\
\hline 0.075 & 5.00 & 12.84 & 1.06 & 3.94 \\
\hline
\end{tabular}

Table 8 Aggregate gradation for 5.0\% asphalt content.

\begin{tabular}{|c|c|c|c|c|}
\hline $\begin{array}{c}\text { Sieve } \\
\text { sizes } \\
(\mathrm{mm})\end{array}$ & $\begin{array}{c}\text { Gradation } \\
\text { of the } \\
\text { mixture } \\
(\% \\
\text { passing })\end{array}$ & $\begin{array}{c}\text { Mineral } \\
\text { of BGA } \\
(\% \\
\text { passing) }\end{array}$ & $\begin{array}{c}\text { Mineral } \\
\text { of } \\
11.50 \% \\
\text { BGA }(\% \\
\text { passing })\end{array}$ & $\begin{array}{c}\text { Aggregate } \\
\text { gradation } \\
\text { needed } \\
(\% \\
\text { passing })\end{array}$ \\
\hline 19.00 & 100.00 & & & 100.00 \\
\hline 12.50 & 92.00 & & & 92.00 \\
\hline 9.50 & 76.00 & & & 76.00 \\
\hline 4.75 & 54.00 & & & 54.00 \\
\hline 2.36 & 38.00 & & & 38.00 \\
\hline 1.18 & 23.00 & 96.55 & 8.88 & 14.12 \\
\hline 0.60 & 18.00 & 85.07 & 7.83 & 10.17 \\
\hline 0.30 & 12.50 & 50.16 & 4.61 & 7.89 \\
\hline 0.075 & 5.00 & 12.84 & 1.18 & 3.82 \\
\hline
\end{tabular}

paction of $2 \times 75$ blows were applied. Marshall criteria were used to assess the properties of the mixture and obtain the optimum asphalt content for each asphalt mixture. Marshall immersion test was conducted for specimens prepared at optimum asphalt content. This test was used to measure the water resistance of the mixture after immersion in the water for 24 hours at $60^{\circ} \mathrm{C}$.

Dynamic stability is included in the requirements for asphalt concrete-wearing course as shown in Table 5. However, wheel tracking test to obtain dynamic stability could not be carried out because the device for this test was not available.

To evaluate the mixture performance subjected to compressive load, indirect tensile strength test was conducted. The specimen was loaded until it failed 
Table 9 Aggregate gradation for $5.5 \%$ asphalt content.

\begin{tabular}{|c|c|c|c|c|}
\hline $\begin{array}{c}\text { Sieve } \\
\text { sizes } \\
(\mathrm{mm})\end{array}$ & $\begin{array}{c}\text { Gradation } \\
\text { of the } \\
\text { mixture } \\
(\% \\
\text { passing })\end{array}$ & $\begin{array}{c}\text { Mineral } \\
\text { of BGA } \\
(\% \\
\text { passing })\end{array}$ & $\begin{array}{c}\text { Mineral } \\
\text { of } \\
12.65 \% \\
\text { BGA }(\% \\
\text { passing })\end{array}$ & $\begin{array}{c}\text { Aggregate } \\
\text { gradation } \\
\text { needed } \\
(\% \\
\text { passing })\end{array}$ \\
\hline 19.00 & 100.00 & & & 100.00 \\
\hline 12.50 & 92.00 & & & 92.00 \\
\hline 9.50 & 76.00 & & & 76.00 \\
\hline 4.75 & 54.00 & & & 54.00 \\
\hline 2.36 & 38.00 & & & 38.00 \\
\hline 1.18 & 23.00 & 96.55 & 9.77 & 13.23 \\
\hline 0.60 & 18.00 & 85.07 & 8.61 & 9.39 \\
\hline 0.30 & 12.50 & 50.16 & 5.08 & 7.42 \\
\hline 0.075 & 5.00 & 12.84 & 1.30 & 3.70 \\
\hline
\end{tabular}

Table 10 Aggregate gradation for $6.0 \%$ asphalt content.

\begin{tabular}{|c|c|c|c|c|}
\hline $\begin{array}{c}\text { Sieve } \\
\text { sizes } \\
(\mathrm{mm})\end{array}$ & $\begin{array}{c}\text { Gradation } \\
\text { of the } \\
\text { mixture } \\
(\% \\
\text { passing) }\end{array}$ & $\begin{array}{c}\text { Mineral } \\
\text { of BGA } \\
(\% \\
\text { passing })\end{array}$ & $\begin{array}{c}\text { Mineral } \\
\text { of } \\
13.80 \% \\
\text { BGA }(\% \\
\text { passing })\end{array}$ & $\begin{array}{c}\text { Aggregate } \\
\text { gradation } \\
\text { needed } \\
(\% \\
\text { passing })\end{array}$ \\
\hline 19.00 & 100.00 & & & 100.00 \\
\hline 12.50 & 92.00 & & & 92.00 \\
\hline 9.50 & 76.00 & & & 76.00 \\
\hline 4.75 & 54.00 & & & 54.00 \\
\hline 2.36 & 38.00 & & & 38.00 \\
\hline 1.18 & 23.00 & 96.55 & 10.66 & 12.34 \\
\hline 0.60 & 18.00 & 85.07 & 9.39 & 8.61 \\
\hline 0.30 & 12.50 & 50.16 & 5.54 & 6.96 \\
\hline 0.075 & 5.00 & 12.84 & 1.42 & 3.58 \\
\hline
\end{tabular}

Table 11 Aggregate gradation for $6.5 \%$ asphalt content.

\begin{tabular}{|c|c|c|c|c|}
\hline $\begin{array}{c}\text { Sieve } \\
\text { sizes } \\
(\mathrm{mm})\end{array}$ & $\begin{array}{c}\text { Gradation } \\
\text { of the } \\
\text { mixture } \\
(\% \\
\text { passing })\end{array}$ & $\begin{array}{c}\text { Mineral of } \\
\text { BGA }(\% \\
\text { passing) }\end{array}$ & $\begin{array}{c}\text { Mineral } \\
\text { of } \\
14.95 \% \\
\text { BGA }(\% \\
\text { passing })\end{array}$ & $\begin{array}{c}\text { Aggregate } \\
\text { gradation } \\
\text { needed } \\
(\% \\
\text { passing) }\end{array}$ \\
\hline 19.00 & 100.00 & & & 100.00 \\
\hline 12.50 & 92.00 & & & 92.00 \\
\hline 9.50 & 76.00 & & & 76.00 \\
\hline 4.75 & 54.00 & & & 54.00 \\
\hline 2.36 & 38.00 & & & 38.00 \\
\hline 1.18 & 23.00 & 96.55 & 11.55 & 11.45 \\
\hline 0.60 & 18.00 & 85.07 & 10.17 & 7.83 \\
\hline 0.30 & 12.50 & 50.16 & 6.00 & 6.50 \\
\hline 0.075 & 5.00 & 12.84 & 1.54 & 3.46 \\
\hline
\end{tabular}

by splitting along the vertical diameter, thus it is the maximum stress during loading. The indirect tensile strength then can be calculated as follows:

$$
\mathrm{ITS}=\frac{2 P_{\max }}{\pi t d}
$$

where, ITS : indirect tensile strength

$P_{\max }:$ the maximum applied load

$t:$ thickness of specimen

$d$ : diameter of specimen
Table 12 Properties of oil derived from the seeds of Calophyllum inophyllum L.

\begin{tabular}{|l|l|c|}
\hline \multicolumn{1}{|c|}{ Laboratory test } & \multicolumn{1}{|c|}{ Testing method } & Results \\
\hline Specific gravity & $\begin{array}{l}\text { SNI 06-2441-1991 } \\
\text { AASHTO T 228-90 }\end{array}$ & 0.953 \\
\hline $\begin{array}{l}\text { Viscosity, } 60^{\circ} \mathrm{C}, \\
(\mathrm{cSt})\end{array}$ & SNI 06-6721-2002 & 35.2 \\
\hline AASHTO T 72-90 & \\
\hline 5oss on heating, & SNI 06 2440-1991 & 1.5 \\
\hline Solubility in $\left.\mathrm{CCl}_{4}\right)$ & AASHTO T 179-88 & \\
\hline Chemical properties: & Gravimetry & 95.21 \\
Carbon $(\%)$ & Spectrometry & 52.18 \\
Nitrogen (\%) & Kjeldahl & 0.01 \\
Sulfur $(\%)$ & Spectrometry & 0.12 \\
\hline
\end{tabular}

Table 13 Properties of pine resin from Pinus merkusii.

\begin{tabular}{|l|l|c|}
\hline \multicolumn{1}{|c|}{ Laboratory test } & \multicolumn{1}{|c|}{ Testing method } & Results \\
\hline Specific gravity & $\begin{array}{l}\text { SNI 06-2441-1991 } \\
\text { AASHTO T 228-90 }\end{array}$ & 1.04 \\
\hline $\begin{array}{l}\text { Viscosity, } 60^{\circ} \mathrm{C}, \\
(\mathrm{cSt})\end{array}$ & $\begin{array}{l}\text { SNI 06-6721-2002 } \\
\text { AASHTO T 72-90 }\end{array}$ & 349.08 \\
\hline Loss on heating, & SNI 06 2440-1991 & 16.98 \\
5 hours, $163^{\circ} \mathrm{C},(\%)$ & AASHTO T 179-88 & \\
\hline Solubility in CCl $\mathrm{Cl}_{4}$ & Gravimetry & 94.1 \\
\hline Chemical properties: & & \\
Carbon $(\%)$ & Spectrometry & 80.15 \\
Nitrogen (\%) & Kjeldahl & 0.03 \\
Sulfur $(\%)$ & Spectrometry & 0.14 \\
\hline
\end{tabular}

\section{RESULTS AND DISCUSSION}

The individual properties of the ingredients of bioflux oil are presented in Table $\mathbf{1 2}$ and Table 13. The results of aggregates and buton granular asphalt properties are shown in Table $\mathbf{1 4}$ and Table 15, and the characteristics of bio-flux oil are presented in Table 16.

As shown in Table 14, aggregates used in this study have met the specifications. The test of impact value was done to determine the toughness of aggregates to resist their disintegration due to impact. Aggregate impact value was linked with hardness of coarse aggregate and measured according to BS 812 . The value of $9.27 \%$ indicates that aggregate is strong enough to withstand the loads due to compaction during construction and traffic load during its service life.

The test of affinity to asphalt was conducted according to AASHTO T-182 and Indonesian National Standard SNI 03-2439-1991. In the methods, aggregates passing through $9.5 \mathrm{~mm}$ and retained on $6.3 \mathrm{~mm}$ sieve size were selected and coated with hot asphalt. After cooling down, the aggregates were immersed in water for a defined time. If the adhesion strength is not sufficient, water is infiltrating between the thin asphalt layer and the aggregate surface, resulting in a weak- 
Table 14 Properties of aggregate

\begin{tabular}{|l|c|c|c|c|c|}
\hline \multicolumn{1}{|c|}{ Laboratory test } & Testing method & \multicolumn{3}{c|}{ Results } & \multirow{2}{*}{ Specification $^{20)}$} \\
\cline { 3 - 5 } & & $\begin{array}{c}\text { Coarse } \\
\text { aggregate }\end{array}$ & $\begin{array}{c}\text { Fine } \\
\text { aggregate }\end{array}$ & Filler & maximum 40 \\
\hline Aggregate impact value (\%) & BS 812 & 9.27 & - & - & minimum 2.5 \\
\hline Bulk specific gravity & AASHTO T 85-88 and & 2.684 & 2.735 & 2.631 & minimum 2.5 \\
Apparent specific gravity & AASHTO T 84-88 & 2.784 & 2.738 & 2.641 & minimum 95 \\
\hline Affinity to asphalt (\%) & SNI 03-2439-1991 & 100 & - & - & \\
& AASHTO T 182-84 & & & & \\
\hline
\end{tabular}

Table 15 Properties of buton granular asphalt.

\begin{tabular}{|c|c|c|c|}
\hline Laboratory test & Testing method & Results & Specification $\mathrm{T} 5 / 20^{1)}$ \\
\hline Asphalt content $(\%)$ & SNI 03-3640-1994 & 20.31 & $18-22$ \\
\hline Water content $(\%)$ & SNI 06-2490-1991 & 0.325 & $<2$ \\
\hline Penetration, $25^{\circ} \mathrm{C}, 5$ seconds, $0.1 \mathrm{~mm}$ & $\begin{array}{l}\text { SNI 06-2456-1991 } \\
\text { AASHTO T 49-89 }\end{array}$ & 9.4 & $\leq 10$ \\
\hline $\begin{array}{l}\text { Sieve sized (\% passing): } \\
2.36 \mathrm{~mm} \\
1.18 \mathrm{~mm} \\
0.60 \mathrm{~mm} \\
0.30 \mathrm{~mm} \\
0.075 \mathrm{~mm}\end{array}$ & $\begin{array}{l}\text { SNI 03-1968-1990 } \\
\text { AASHTO T 27-88 }\end{array}$ & $\begin{array}{l}100 \% \\
96.55 \% \\
85.07 \% \\
50.16 \% \\
12.84 \%\end{array}$ & $\begin{array}{c}100 \% \\
\text { minimum } 95 \% \\
- \\
- \\
-\end{array}$ \\
\hline $\begin{array}{l}\text { Bulk specific gravity } \\
\text { Apparent specific gravity }\end{array}$ & $\begin{array}{l}\text { SNI 03-1970-1990 } \\
\text { AASHTO T } 84-88 \\
\end{array}$ & $\begin{array}{l}1.993 \\
2.106 \\
\end{array}$ & $\begin{array}{l}- \\
-\end{array}$ \\
\hline
\end{tabular}

Table 16 Properties of bio-flux oil.

\begin{tabular}{|l|c|c|c|c|c|c|c|}
\hline \multicolumn{1}{|c|}{ Laboratory test } & Testing method & \multicolumn{5}{|c|}{ Results } & Specification $^{21)}$ \\
\cline { 3 - 8 } & & B1 & B2 & B3 & B4 & B5 & \\
\hline Flash point $\left({ }^{\circ} \mathrm{C}\right)$ & $\begin{array}{c}\text { SNI 06-2433-1991 } \\
\text { AASHTO T 48-89 }\end{array}$ & 218 & 190 & 224 & 208 & 223 & minimum 200 \\
\hline Specific gravity & $\begin{array}{c}\text { SNI 06-2441-1991 } \\
\text { AASHTO T 228-90 }\end{array}$ & 0.993 & 0.999 & 0.998 & 1.007 & 1.007 & minimum 0.95 \\
\hline Viscosity, 60 & & & & & & & \\
\hline $\begin{array}{l}\text { LASt) } \\
163^{\circ} \mathrm{C}(\%)\end{array}$ & $\begin{array}{c}\text { SNI 06-6721-2002 } \\
\text { AASHTO T 72-90 }\end{array}$ & 758 & 1550.5 & 900.33 & 2423.5 & 1604.4 & - \\
\hline
\end{tabular}

ening or even partial removal of the asphalt film. In this study, $100 \%$ affinity to asphalt indicates that the surface area of aggregate can be well coated. Moreover, bulk and apparent specific gravity of aggregates can be used to assess their compactibility. Since the results are within the specifications, these aggregates have good compaction properties.

Table 15 shows the engineering properties of buton granular asphalt. To separate asphalt and aggregate, buton granular asphalt was diluted with a solvent and extracted by centrifuge extractor. Asphalt extraction has been done for a long time, using both organic and inorganic solvents. Various kinds of organic solvents have been tested on natural asphalt extraction; for example, kerosene, hexane, TCE, and npropyl bromide ${ }^{22)}$. In this study, kerosene was used as the solvent. Distillation was then conducted to separate the solvent and asphalt. The asphalt content was $20.31 \%$ and this value was dependent on its origin.
As a mining material, buton granular asphalt contains water naturally due to the weather. However, before use, buton granular asphalt must satisfy the water content requirement as stated in Table 2 . Since the mixture containing buton natural asphalt was mixed in hot condition, the water evaporated in this process.

Penetration of $9.4 \mathrm{dmm}$ indicates that the asphalt of asbuton is hard. Maximum particle size of buton granular asphalt is $2.36 \mathrm{~mm}$ and other properties have satisfied the specifications.

As seen in Table 16, the viscosity of each bio-flux oil is different due to the difference in the composition of constituent materials. This study aims to know the material composition of bio-flux oil that produces the best performance, so that the content of modifier in the mixture may be fixed for all bio-flux oil samples. As shown in Table 16, bio-flux oil B2 failed to meet all the requirements. Therefore, the next step was to make mixtures that contained bio-flux oil B1, B3, B4, 


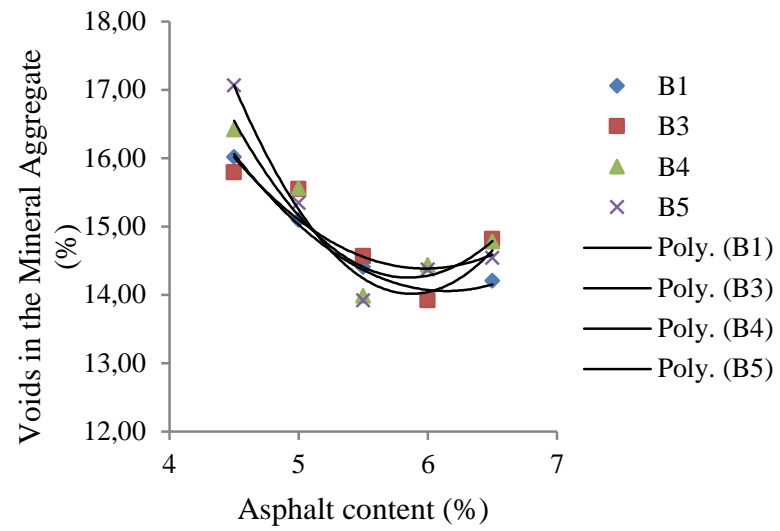

Fig.1 VMA versus asphalt content.

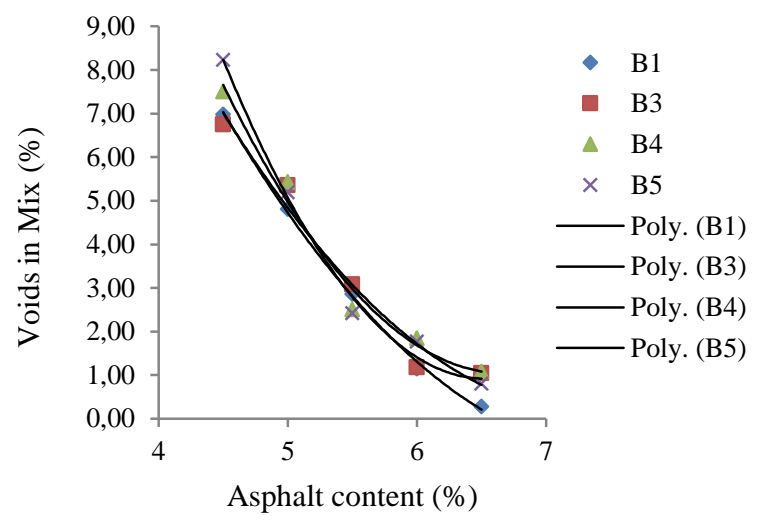

Fig.2 VIM versus asphalt content.

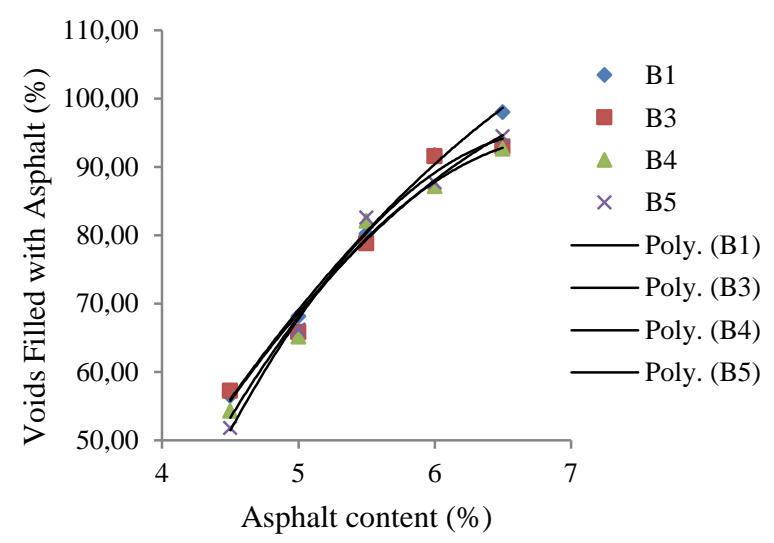

Fig.3 VFA versus asphalt content.

and B5. The results of Marshall test and volumetric properties are presented in Fig. 1 up to Fig. 6.

The relation between voids in the mineral aggregate (VMA) and asphalt content is illustrated in Fig. 1. VMA exist between the aggregate particles in the compacted mix, including spaces filled with asphalt binder. VMA represent the space available to accommodate the effective volume of asphalt binder and air voids in the mix. The effective volume of asphalt is the total volume of asphalt binder in the mix minus the volume of asphalt binder absorbed into the aggre-

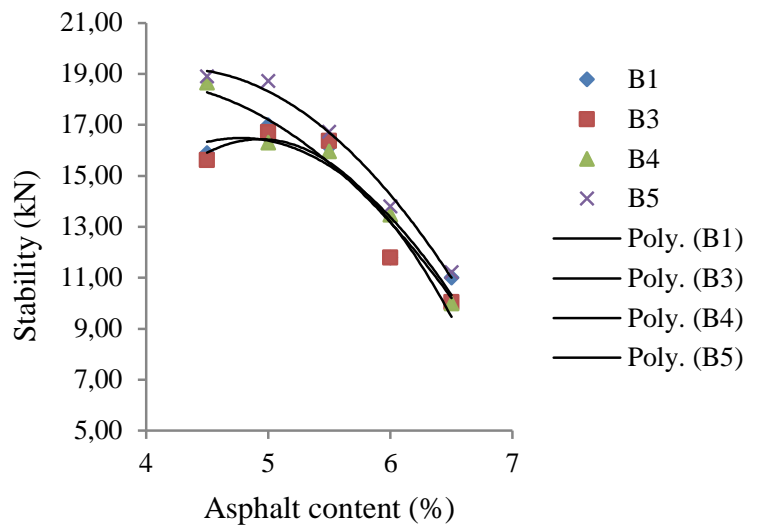

Fig.4 Stability versus asphalt content.

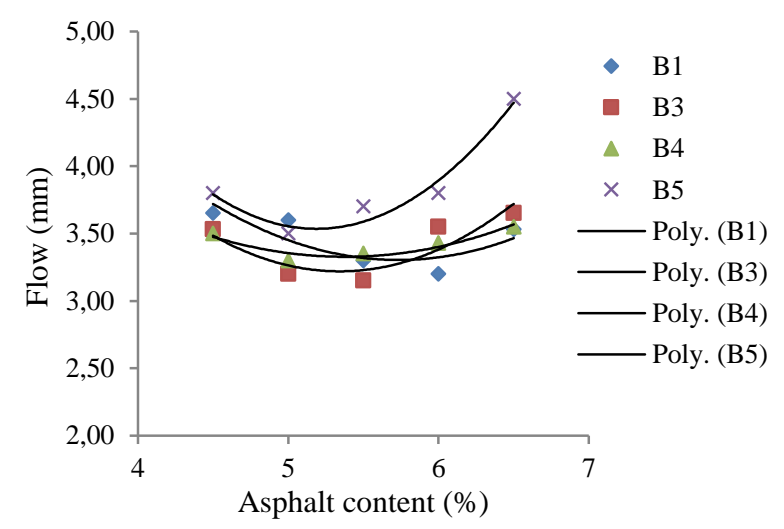

Fig.5 Flow versus asphalt content.

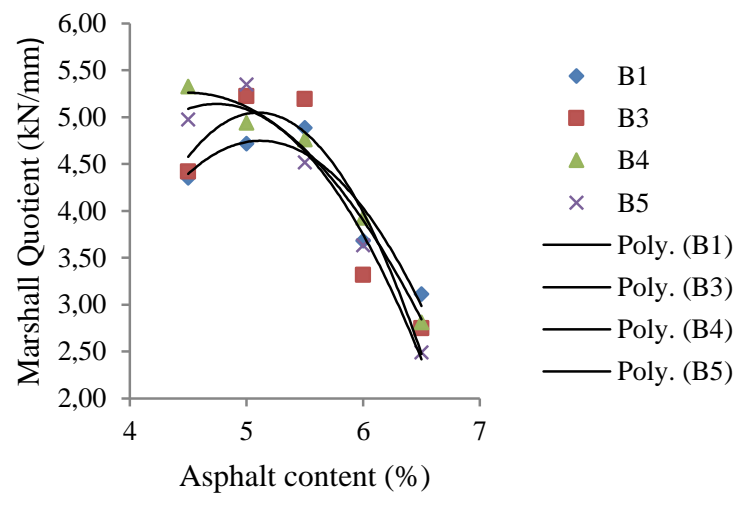

Fig.6 Marshall Quotient versus asphalt content.

gate. Based on that figure, the value of VMA is decreased until certain asphalt content finally increases. The void spaces reach a small value when compacted at the optimum asphalt content. However, increasing the content of asphalt tends to make the mixture too wet and its VMA start to increase.

Fig. 2 shows the relation between voids in mix (VIM) and asphalt content. From that figure, it can be seen that the value of VIM tends to decrease as the content of asphalt in the mixture increases. As presented in Table 6, the higher the asphalt content, the 
more the amount of buton granular asphalt and bioflux oil added. Thus, the void is filled by said asphalt from the buton granular asphalt and bio-flux oil. VIM laid between $3.5 \%$ and $5.5 \%$ are required to ensure that the void in the mixture can adapt to additional compaction during the service life of pavement and to prevent bleeding. Further, the value of VIM should not be more than $5.5 \%$ to avoid penetration of air and water to the pavement.

Fig. 3 shows the relation between voids filled with asphalt (VFA) and asphalt content. As shown in that figure, the value of VFA tends to increase as asphalt content increases. The higher the asphalt content in the mix, the more space becomes available for asphalt film. The thickness of asphalt film is related to asphalt mix durability. Thick asphalt films provide durability benefits. They tend to seal the pavement better than thin film and do not allow penetration of large volume of air and water. The minimum requirement of VFA is $65 \%$, and it can be satisfied at the content of asphalt in the range of $4.8 \%-6.5 \%$.

The relation between Marshall stability and asphalt content is shown in Fig. 4. Marshall stability is the ability of pavement to receive loading without damage, such as permanent deformation or bleeding. According to Brown et al., Marshall test can be categorized as an empirical test to characterize the permanent deformation response of asphalt pavement materials $^{23)}$. Based on that figure, Marshall stabilities for all mixtures have the same phenomenon. For each of the mixtures using bio-flux oil B1 and B3, Marshall stability reaches its peak at the asphalt content of 5\%. Moreover, increasing buton granular asphalt and bio-flux oil at asphalt content more than $5 \%$ decreases Marshall stability. As shown in Table 6, the higher the asphalt content, the larger the amount of buton granular asphalt and bio-flux oil in the mixture. Increasing the amount of buton granular asphalt and bio-flux oil reduced internal friction of aggregates due to the thickness of film asphalt and thus decreased the Marshall stability. With a minimum Marshall stability value set at $9.81 \mathrm{kN}$, all mixtures in this study met the specifications.

From Fig. 5, it can be seen that the flow of the mixture tends to decrease until it reaches minimum, then increases as the asphalt content goes higher. The flow value can be read using a flowmeter and indicates the deformation of the mixture due to loading until failure. Increasing asphalt content tends to make the mixture more dense, thus deformation is small during applied loading. However, increasing the asphalt content more than its optimum value tends to make the mixture more flexible, thus increases the flow value.

The relation between Marshall Quotient (MQ) and asphalt content is shown in Fig. 6. The value of MQ is obtained by dividing Marshall stability by the flow value. Because the value of MQ is strongly influenced by Marshall stability and flow, the phenomenon in Fig. 4 is almost the same as that in Fig. 6. MQ is an indicator of the resistance against the deformation of asphalt concrete. As mentioned above, this is an empirical stiffness value to evaluate the strength of asphalt mixture. A higher MQ value indicates a stiffer mixture and, hence, indicates that the mixture is likely to be more resistant to permanent deformation ${ }^{23)}$.

Based on Fig. 1 to Fig. 6 and using the Marshall standard design criteria, the optimum asphalt content was obtained for each mixture containing bio-flux oil. The optimum asphalt content can be determined by the diagram of bars as presented in Fig. 7 to Fig. 10 . The average value in which the asphalt range fulfills all the requirements of the Marshall design criteria was taken as the optimum asphalt content. For the mixture containing bio-flux oil B1, all standard design criteria can be satisfied at the range of $4.8 \%$ $5.0 \%$ asphalt content; thus, the optimum asphalt content of $4.9 \%$ was chosen. The mixtures containing bio-flux oil B3, B4, and B5 satisfied all the requirements at the range of $4.9 \%-5.1 \%$; thus, optimum asphalt content was $5.0 \%$.

Furthermore, the values of VMA, VIM, VFA, Marshall stability, flow, Marshall Quotient, Marshall immersion, and ITS at the optimum asphalt content are presented in Fig. 11 to Fig. 18.

From Fig. 11 to Fig. 18, it can be seen that the performance of the mixtures is strongly influenced by the oil composition derived from the seeds of Calophyllum inophyllum L. and pine resin. As shown in Fig. 11 and Fig. 12, both VMA and VIM values tend to increase as the viscosity of bio-flux oil increases. However, the values of VMA and VIM in the mixture containing bio-flux oil B5 are smaller than the values of VMA and VIM in the mixture containing bio-flux oil B3, although the viscosity of bio-flux oil B5 is higher than the viscosity of bio-flux oil B3. This indicates that the proportion of components in bio-flux oil B5 exhibits a stronger binding of aggregate particles. As a result, the mixture containing bio-flux oil B5 becomes more dense and the VMA and VIM values decrease.

As seen in Fig. 11 and Fig. 13, the VMA and VFA have an inverse relationship. The higher the VMA value, the lower its VFA. When the value of VMA increases, the amount of voids between aggregate particles produced tends to increase. Therefore, the area that is coated by the asphalt tends to be larger resulting in thinner film asphalt.

The results of this study show that Marshall stability tends to increase as the value of VMA decreases. When the value of VMA decreases, the interlocking between aggregate particles tends to increase resulting in higher stability. However, the stability of the 


\begin{tabular}{|c|c|c|c|c|c|c|c|c|c|c|c|c|c|c|c|c|c|c|c|c|c|}
\hline \multirow[t]{3}{*}{ Mixture properties } & \multicolumn{21}{|c|}{ Asphalt content satisfied the requirements } \\
\hline & \multicolumn{5}{|c|}{4} & \multicolumn{10}{|c|}{5} & \multicolumn{6}{|c|}{6} \\
\hline & 5 & 6 & 7 & 8 & 9 & 0 & 1 & 2 & 3 & 4 & 5 & 6 & 7 & 8 & 9 & 0 & 1 & 2 & 3 & 4 & 5 \\
\hline Voids in the mineral aggregate & & & & & & & & & & & & & & & & & & & & & \\
\hline Voids in mix & & & & & & & & & & & & & & & & & & & & & \\
\hline Voids filled with asphalt & & & & & & & & & & & & & & & & & & & & & \\
\hline Stability & & & & & & & & & & & & & & & & & & & & & \\
\hline Flow & & & & & & & & & & & & & & & & & & & & & \\
\hline Marshall Quotient & & & & & & & & & & & & & & & & & & & & & \\
\hline Optimum asphalt content $=4.9 \%$ & & & & & & & & & & & & & & & & & & & & & \\
\hline
\end{tabular}

Fig.7 Range diagram for the mixture containing bio-flux oil B1.

\begin{tabular}{|c|c|c|c|c|c|c|c|c|c|c|c|c|c|c|c|c|c|c|c|c|}
\hline \multirow[t]{3}{*}{ Mixture properties } & \multicolumn{20}{|c|}{ Asphalt content satisfied the requirements } \\
\hline & \multicolumn{5}{|c|}{4} & \multicolumn{9}{|c|}{5} & \multicolumn{6}{|c|}{6} \\
\hline & 5 & 6 & 7 & 8 & 9 & 1 & 2 & 3 & 4 & 5 & 6 & 7 & 8 & 9 & 0 & 1 & 2 & 3 & 4 & 5 \\
\hline Voids in the mineral aggregate & & & & & & & & & & & & & & & & & & & & \\
\hline Voids in mix & & & & & & & & & & & & & & & & & & & & \\
\hline Voids filled with asphalt & & & & & & & & & & & & & & & & & & & & \\
\hline Stability & & & & & & & & & & & & & & & & & & & & \\
\hline Flow & & & & & & & & & & & & & & & & & & & & \\
\hline Marshall Quotient & & & & & & & & & & & & & & & & & & & & \\
\hline Optimum asphalt content $=5.0 \%$ & & & & & & & & & & & & & & & & & & & & \\
\hline
\end{tabular}

Fig.8 Range diagram for the mixture containing bio-flux oil B3.

\begin{tabular}{|c|c|c|c|c|c|c|c|c|c|c|c|c|c|c|c|c|c|c|c|c|c|}
\hline \multirow{3}{*}{ Mixture properties } & \multicolumn{21}{|c|}{ Asphalt content satisfied the requirements } \\
\hline & \multicolumn{5}{|c|}{4} & \multicolumn{10}{|c|}{5} & \multicolumn{6}{|c|}{6} \\
\hline & 5 & 6 & 7 & 8 & 9 & 0 & 1 & 2 & 3 & 4 & 5 & 6 & 7 & 8 & 9 & 0 & 1 & 2 & 3 & 4 & 5 \\
\hline Voids in the mineral aggregate & & & & & & & & & & & & & & & & & & & & & \\
\hline Voids in mix & & & & & & & & & & & & & & & & & & & & & \\
\hline Voids filled with asphalt & & & & & & & & & & & & & & & & & & & & & \\
\hline Stability & & & & & & & & & & & & & & & & & & & & & \\
\hline Flow & & & & & & & & & & & & & & & & & & & & & \\
\hline Marshall Quotient & & & & & & & & & & & & & & & & & & & & & \\
\hline Optimum asphalt content $=5.0 \%$ & & & & & & & & & & & & & & & & & & & & & \\
\hline
\end{tabular}

Fig.9 Range diagram for the mixture containing bio-flux oil B4.

\begin{tabular}{|c|c|c|c|c|c|c|c|c|c|c|c|c|c|c|c|c|c|c|c|c|c|}
\hline \multirow[t]{3}{*}{ Mixture properties } & \multicolumn{21}{|c|}{ Asphalt content satisfied the requirements } \\
\hline & \multicolumn{5}{|c|}{4} & \multicolumn{10}{|c|}{5} & \multicolumn{6}{|c|}{6} \\
\hline & 5 & 6 & 7 & 8 & 9 & 0 & 1 & 2 & 3 & 4 & 5 & 6 & 7 & 8 & 9 & 0 & 1 & 2 & 3 & 4 & 5 \\
\hline Voids in the mineral aggregate & & & & & & & & & & & & & & & & & & & & & \\
\hline Voids in mix & & & & & & & & & & & & & & & & & & & & & \\
\hline Voids filled with asphalt & & & & & & & & & & & & & & & & & & & & & \\
\hline Stability & & & & & & & & & & & & & & & & & & & & & \\
\hline Flow & & & & & & & & & & & & & & & & & & & & & \\
\hline Marshall Quotient & & & & & & & & & & & & & & & & & & & & & \\
\hline Optimum asphalt content $=5.0 \%$ & & & & & & & & & & & & & & & & & & & & & \\
\hline
\end{tabular}

Fig.10 Range diagram for the mixture containing bio-flux oil B5. 


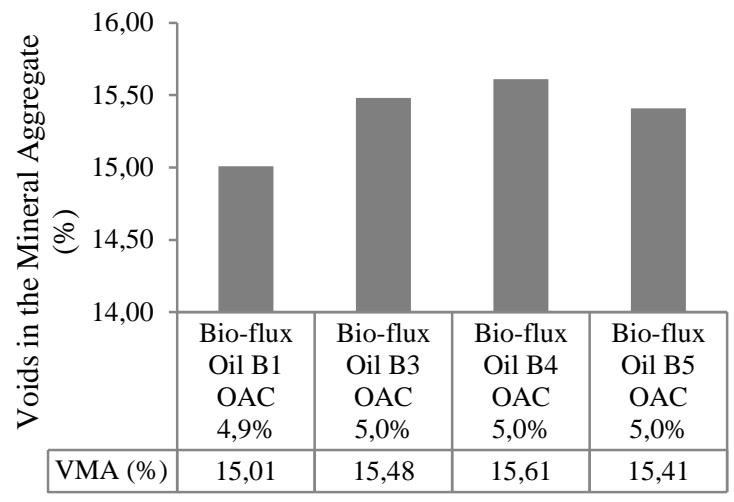

Fig.11 VMA at the optimum asphalt content.

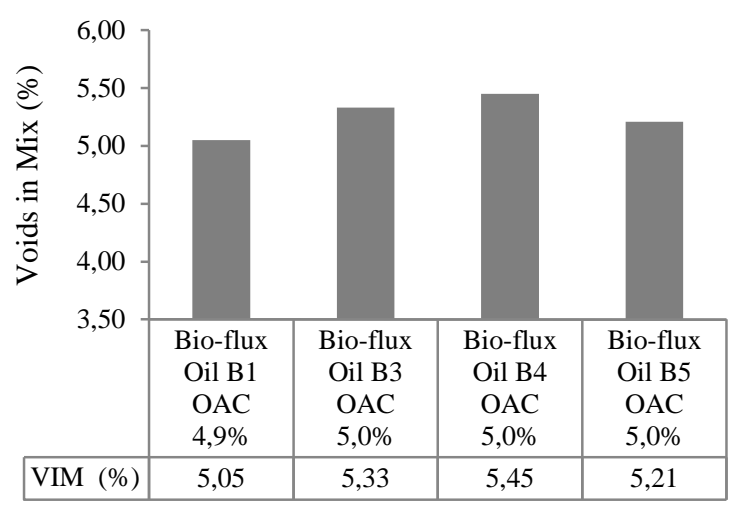

Fig.12 VIM at the optimum asphalt content.

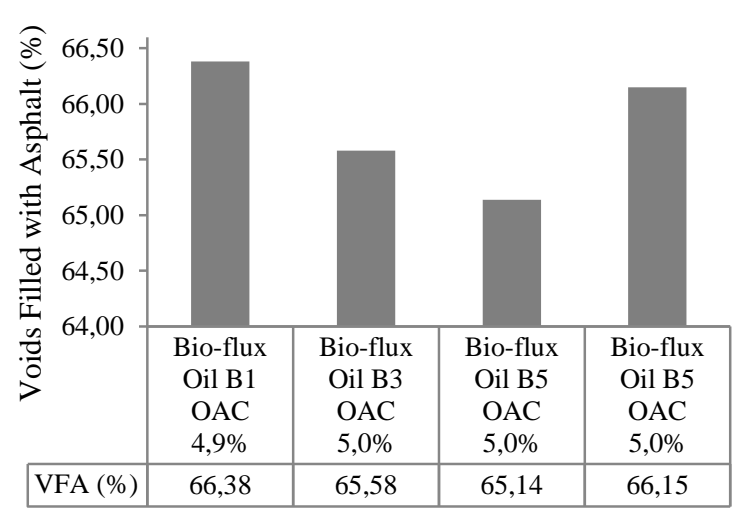

Fig.13 VFA at the optimum asphalt content.



Fig.14 Stability at the optimum asphalt content.

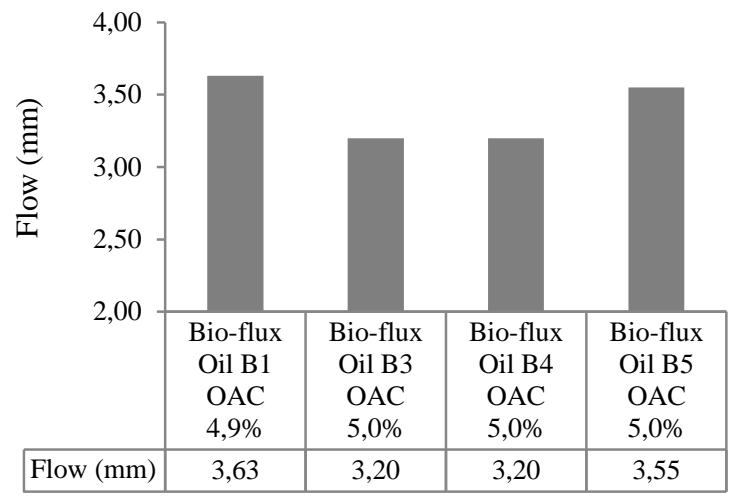

Fig.15 Flow at the optimum asphalt content.

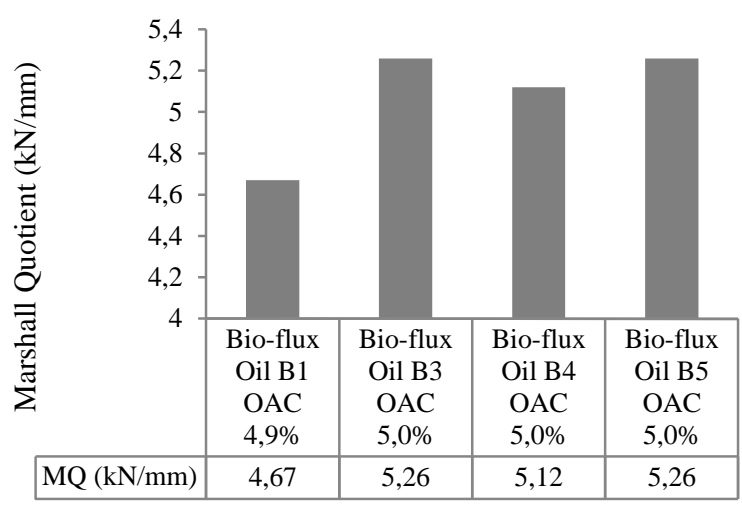

Fig.16 MQ at the optimum asphalt content.

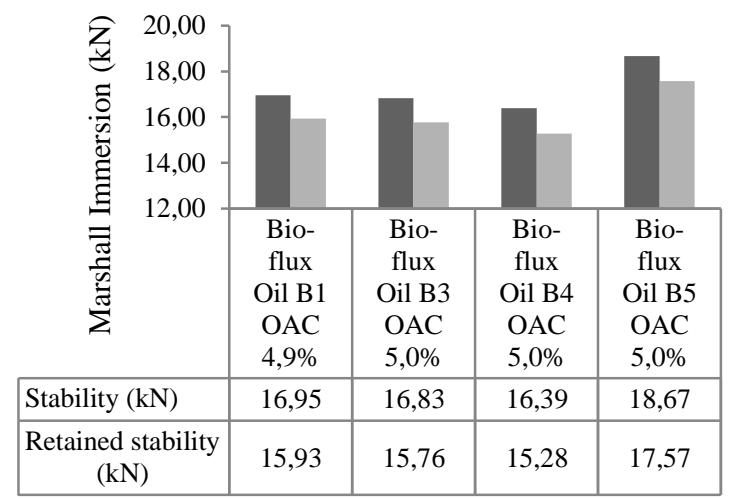

Fig.17 Marshall Immersion at the optimum asphalt content.

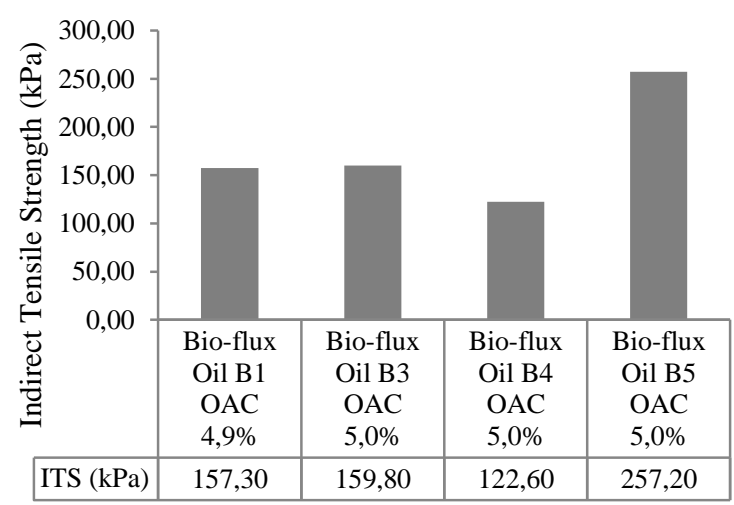

Fig.18 ITS at the optimum asphalt content. 
mixture containing bio-flux oil B5 is higher than the stability of the mixture containing bio-flux oil B1, although the VMA value of the mixture containing B1 is lower than the value of VMA in the mixture containing bio-flux oil B5. In Fig. 13 and Fig. 14, Marshall stability tends to increase as the value of VFA increases. This is because the thicker the film asphalt, the stronger the bond between aggregate particles. However, the stability of the mixture containing bio-flux oil B5 is higher than the stability of the mixture containing bio-flux oil B1, although the VFA value of the mixture containing $B 1$ is higher than the value of VFA in the mixture containing bio-flux oil B5. This phenomenon is indicated because of the proportion of components in bio-flux oil B5.

From Fig. 11 and Fig. 15, it can be seen that the flow value tends to decrease as the value of VMA increases. When VMA increases, the distance between aggregate particles increases, so that the mixture is less resistant to deformation. In Fig. 13 and Fig. 15, the flow value tends to increase as the value of VFA increases. This is because the thicker the film asphalt, the higher the resistance of the mixture to deformation. The flow value in the mixture containing bioflux oil B3 is the same as the flow value in the mixture containing bio-flux oil B4 because this value is influenced by the VMA and VFA.

As mentioned above, the value of MQ is obtained by dividing stability by the flow. From Fig. 16, it can be seen that the mixtures containing bio-flux oil B3 and B5 have the same MQ values. This is because the mixture containing bio-flux oil B5 has higher stability and flow as shown in Fig. 14 and Fig. 15.

The value of retained stability is presented in Fig. 17. As Marshall immersion is the ratio of Marshall stability of the soaked specimens to the standard Marshall, the index of retained stability in the mixture containing bio-flux oil B1, B3, B4, and B5 are $93.98 \%, 93.64 \%, 93.23 \%$, and $94.11 \%$ respectively. Based on this result, the index of retained stability decreases as VIM increases, as shown in Fig. 12. This indicates that the mixture having low VIM value will stand better and will be more resistant against water. In addition, the index of retained stability decreases as VFA decreases. This is because the thinner asphalt film is more easily penetrated by water. Due to the proportion of components in bio-flux oil, the highest percentage of retained stability is obtained from the mixture containing bio-flux oil B5.

Fig. 18 presents the result of Indirect Tensile Strength (ITS) test of the mixture for each bio-flux oil contained. The tensile strain at failure determined from ITS tests is useful in predicting the cracking potential of mixes. Mixes that can tolerate high strains prior to failure are more likely to resist cracking, compared to the mixtures that cannot tolerate high strains ${ }^{24)}$. Fig. 18 shows that the value of ITS tends to decrease as the value of VMA increases. The increasing VMA value tends to decrease the friction between the aggregate particles and reduce the bond in the mixture. The ITS test also can be used to evaluate the moisture susceptibility of an asphalt mixture. A higher ITS indicates that the mixture will perform well with good resistance to moisture damage. From Fig. 18, it can be seen that the highest value of ITS is the mixture containing bio-flux oil B5.

To choose the recommended bio-flux oil, all the results were analyzed. The value of VMA in the mixture containing bio-flux oil B1 is too close to the $15 \%$ minimum requirement, so that bio-flux oil $\mathrm{B} 1$ is not recommended. The value of VIM in the mixture containing bio-flux oil B4 is too close to the 5.5\% maximum requirement. This indicates that the mixture is more vulnerable to water penetration; thus, bio-flux oil B4 is not recommended. Moreover, the flow value in the mixture containing bio-flux oil B3 is lower than the flow value in the mixture containing bio-flux oil B5. This indicates that the mixture containing bioflux oil B5 is more flexible to withstand the loading. From the results of Marshall stability, retained stability, and ITS tests, the mixture containing bio-flux oil B5 shows a better performance than others.

In the Marshall procedure of MS-2, a laboratory compaction of 75 blows on the two faces of a Marshall stability specimen was regarded as heavy traf$\mathrm{fic}^{25)}$. The specimens in this study were subjected to compaction of 75 blows on each side, and the mixture containing bio-flux oil B5 fulfilled the requirements of Marshall stability, flow, VIM, etc. As stated previously, heavy traffic is intended to withstand 8,000 20,000 vehicles/day, thus it can be concluded that the mixture recommended by this study has satisfied that condition.

\section{CONCLUSIONS}

Based on the results, the following conclusions are drawn:

- Bio-flux oil introduced in this study consisted of the oil derived from the seeds of oil nut tree (Calophyllum inophyllum L.), crude pine resin from pine tree (Pinus merkusii), and other ingredients with viscosity value in the range of $758 \mathrm{cSt}$ to $2423.5 \mathrm{cSt}$ at $60^{\circ} \mathrm{C}$. The viscosity value in the stated range must fulfill the flash point requirement in order to provide working safety.

- The use of buton granular asphalt in asphalt concrete-wearing course is indicated to withstand heavy traffic by applying bio-flux oil, which has the viscosity of $1604.4 \mathrm{cSt}$ at $60^{\circ} \mathrm{C}$, 1.007 of specific gravity, $0.46 \%$ of loss on heating at $163^{\circ} \mathrm{C}$ and $223^{\circ} \mathrm{C}$ of flash point. 
ACKNOWLEDGMENT: This study is part of a research funded by the Ministry of Research and Technology, Indonesia. The author gratefully acknowledges the support provided by the Laboratory of Highways and Transportation Engineering, Faculty of Engineering, Mataram University, and the Laboratory of Analytical Chemistry, Faculty of Mathematics and Natural Sciences, Mataram University.

\section{REFERENCES}

1) Directorate General of Bina Marga : Book I General Description, Guidelines for The Use of Buton Granular Asphalt, Department of Public Works, Jakarta (in Indonesian), 2006.

2) Directorate General of Bina Marga, Construction Guidelines of Asbuton with Aggregate, No.09/PT/B/1983, Jakarta (in Indonesian), 1983.

3) Agus, R. : The Development of Buton Granular Asphalt Technology for Road Pavement, Highway and Transportation Engineering Magazine, No. 092, July 1998, pp. 77-78, Indonesian Road Development Association, Jakarta (in Indonesian), 1998.

4) Epps, J. A., Little, D. N., Holmgreen, R. J. and Terrel, R. L. : Guidelines for Recycling Pavement Materials, Transportation Research Board, National Research Council, Washington, D. C., 1980.

5) Bailey, H. and Phillips, P. : Asphalt Rejuvenation, United Kingdom Patent Application No. GB 2462322 A, 2010.

6) Huang, S. C., Salomon, D. and Haddock, J. E. : Workshop Introduction, Transportation Research Circular E-C165, p. 1, Transportation Research Board, Washington, D.C, 2012.

7) Wahyudi, M. and Yuniarti, R. : Design of Asphalt Pavement Recycled Mixture with Jatropha Curcas Oil as Rejuvenating Agent, Research Journal of Mataram University, Vol. 2, No. 17, pp. 14-23, Mataram (in Indonesian), 2012.

8) Yuniarti, R. : Bio-Flux Oil Performance in Buton Asphalt Mixture, Proceedings of the Sixth National Conference on Civil Engineering, The University of Trisakti, pp. MB1-MB7, Jakarta (in Indonesian), 2012.

9) Coppen, J. J. W. and Hone G. A. : Gum Naval Stores : Turpentine and Rosin from Pine Resin, Natural Resources Institute, Food and Agriculture Organization of The United Nations, Rome, 1995.

10) Perhutani, P. : Consolidation Business Process Towards Excellent Perhutani, Annual Report, Jakarta, 2012.

11) Neubert, T. C. : Asphalt Containing Gilsonite, Reactive Oil and Elastomer, Patent Number 5023282, United States Patent $\mathcal{E}$ Trademark Office, 1991.

12) Ballenger, Jr. W. T. and Light, Sr. T. J. : Antistripping
Asphalt Compositions and Additives Used Therein, Patent Number 5,164,002, United States Patent $\mathcal{E}$ Trademark Office, 1992.

13) Freisthler, M. : Bituminous Composition, Patent Number 7,008,670 B1, United States Patent $\mathcal{E}$ Trademark Office, 2006.

14) Williams, R. C., Satrio, J., Rover, M., Brown, R. C. and Teng, S. : Utilization of Fractionated Bio-Oil in Asphalt, Presented at the 88th Annual Meeting of the Transportation Research Board, Washington, D. C., 2009.

15) Nigen-Chaidron, S. and Porot, L. : Rejuvenating Agent and Process for Recycling of Asphalt, Patent Number US 7,811,372 B2, United States Patent $\mathcal{E}$ Trademark Office, 2010.

16) Laurens, C., Nadjar, H., Rebuffatti, A. C., Rodrigues, C., Wang, K. and Soubigou, C. : Binder Composition and Asphalt Mixture, Patent Number 8,076,399 B2, United States Patent $\mathcal{E}$ Trademark Office, 2011.

17) Zaumanis, M., Mallick, R. B. and Frank, R. : Use of Rejuvenators for Production of Sustainable High Content Rap Hot Mix Asphalt, The XXVIII International Baltic Road Conference, 2013.

18) Directorate General of Bina Marga : Book III Hotmix Asphalt with the Processed Buton Granular Asphalt, Guidelines for The Use of Buton Granular Asphalt, Department of Public Works, Jakarta (in Indonesian), 2006.

19) Directorate General of Bina Marga : Guidelines for Implementation of Buton Granular AsphaltAggregate Layer and Thin Layer, Jakarta (in Indonesian), 1998.

20) Department of Public Works : Hotmix Asphalt Specifications, Public Works Publisher, Jakarta (in Indonesian), 2003.

21) Department of Public Works : Hotmix Buton Granular Asphalt, Pd T-07-2004-B, Jakarta (in Indonesian), 2004.

22) Devianto, I. M., Budianta, 1. A., Susanto, B. H. and Nasikin, M. : Asphalt Production from Asbuton Rock by Extraction Using Weak Acid, Chemical and $M a$ terials Engineering, Vol. 1, No. 2, pp. 35-42, 2013, http: //www . hrpub.org

23) Brown, E. R., Kandhal, P. S. and Zhang, J. : Performance Testing For Hot Mix Asphalt, NCAT Report 01-05, National Center for Asphalt Technology, Auburn University, Alabama, 2001.

24) Aodah, H. H., Kareem, Y. N. A. and Chandra, S. : Performance of Bituminous Mixes with Different Aggregate Gradations and Binders, International Journal of Engineering and Technology (IJET), Vol. 2, No. 11, pp. 1802-1812, UK, 2012.

25) Asphalt Institute : Mix Design Method for Asphalt Concrete and Other Hot-Mix Types, Asphalt Institute Manual Series No. 2 (MS-2), Sixth Edition, 1996.

(Received February 6, 2014) 